\title{
Constitutive and Gamma Ray Modified Uptake of Labelled Precursors into the DNA of Dictyostelium discoideum during Development
}

\author{
By R. A. DEERING \\ Molecular and Cell Biology Program, The Pennsylvania State University, University Park, \\ Pennsylvania 16802, U.S.A.
}

(Received 7 January 1982)

\begin{abstract}
The uptake of the labelled precursors, thymidine, deoxyadenosine and adenine, into the nuclear and mitochondrial DNA of the cellular slime mould, Dictyostelium discoideum, at various stages of development was studied. Labelling of the different species of DNA, nuclear main-band, mitochondrial, and satellite, was analysed by $\mathrm{CsCl}$ gradients using the AT-specific drug netropsin to enhance the density resolution. Constitutive and gamma ray modified uptake patterns were obtained. During early development, through late aggregation, constitutive uptake of thymidine and deoxyadenosine was exclusively into DNA at the density of mitochondrial and nuclear satellite I DNA, believed to be primarily due to mitochondrial DNA labelling. Labelled adenine was not incorporated into any DNA before early culmination. During the period of early culmination uptake of all three of these precursors into the main-band nuclear DNA increased dramatically, to considerably exceed uptake into the mitochondrial DNA. The molecular basis for these constitutive uptake patterns during development is not understood, but they appear to involve developmentally associated periods of DNA replication in some or all of the cells, possibly accompanied by changes in precursor transport and/or pool sizes that are different for the mitochondrial and nuclear DNA metabolic pathways. Early in development gamma rays had little effect on the constitutive uptake of precursor into the mitochondrial DNA but induced new dose-dependent uptake of thymidine and deoxyadenosine into the nuclear DNA. This unscheduled nuclear DNA synthesis may be a manifestation of gamma ray induced repair replication. At the early culmination stage gamma rays severely depressed the constitutive uptake of thymidine, deoxyadenosine and adenine into the nuclear DNA, to a level of about $10 \%$ at $20 \mathrm{krad}$. Higher doses induced a slight increase over this level. These changes may be due to the inhibition of the constitutive semiconservative replication by low gamma ray doses with the superposition of some induced repair replication.
\end{abstract}

\section{INTRODUCTION}

The cellular slime mould Dictyostelium discoideum in conditions of sufficient nutrient undergoes vegetative growth as amoeboid cells, but upon starvation begins synchronous development characterized by aggregation and differentiation to stalk and spore cells (Bonner, 1967; Loomis, 1975). Although it has been rather generally accepted that little if any cell division or DNA replication occurs during this development, reports to the contrary have appeared (Bonner \& Frascella, 1952; Katz \& Bourguignon, 1974; Zada-Hames \& Ashworth, 1978).

The majority of the DNA of $D$. discoideum bands at two densities in $\mathrm{CsCl}$ gradients, mainband nuclear (n) DNA at $1.682 \mathrm{~g} \mathrm{ml}^{-1}$ and mitochondrial (m) DNA at $1.688 \mathrm{~g} \mathrm{ml}^{-1}$. The mainband n-DNA comprises about $60 \%$ of the total DNA, m-DNA about $30 \%$, and two nuclear satellite DNAs the remaining $10 \%$. These satellite(s) DNAs have densities of about $1.688 \mathrm{~g} \mathrm{ml}^{-1}$ (I, about the same as m-DNA) and $1.693 \mathrm{~g} \mathrm{ml}^{-1}$ (II) (Sussman \& Rayner, 1971 ; Firtel \& Bonner, 1972; Deering \& Jensen, 1973; Firtel et al., 1976). 
Several aspects of DNA repair have been studied in this organism (Deering \& Jensen, 1973; Guialis \& Deering, 1976; Welker \& Deering, 1978; Ford \& Deering, 1979; Kielman \& Deering, 1980; Clark \& Deering, 1981; Ohnishi et al., 1981). It was of interest to determine if radiationinduced repair replication of DNA, potentially observable as 'unscheduled' DNA synthesis, could be detected during the development of $D$. discoideum, possibly in the absence of any background of constitutive synthesis of DNA. However, the initial experiments demonstrated that reproducible and significant stage-specific uptake of labelled precursors into the DNA was occurring during development even in the absence of any DNA-damaging treatment. This constitutive uptake was modified in specific ways by gamma irradiation. The constitutive and gamma ray modified patterns of uptake of several precursors into $n$ - and m- (or m,s)-DNA at various stages of development are presented and discussed.

\section{METHODS}

Cells. Dictyostelium discoideum NC-4 was used throughout. The cells were grown in liquid suspensions of Escherichia coli $\mathrm{B} / \mathrm{r}$ at $23{ }^{\circ} \mathrm{C}$ with aeration, as previously described (Deering et al., 1970). For most experiments, cells in stationary phase at $2 \times 10^{7} \mathrm{ml}^{-1}$ were washed with phosphate-buffered saline (PBS) (Deering et al., 1970) by differential centrifugation and then gently aerated at $23^{\circ} \mathrm{C}$ at $4 \times 10^{7} \mathrm{ml}^{-1}$ in PBS for 8 to $10 \mathrm{~h}$ before depositing on Millipore filters for development (see later). This incubation period in buffer with no nutrient made the cells aggregation-competent so that aggregation started immediately after the cells were deposited on the filters. Aggregation was completed by $6 \mathrm{~h}$ and development to fruiting bodies finished by $17 \mathrm{~h}$. In a few experiments, development was initiated with cells that had not undergone the 8 to $10 \mathrm{~h}$ preincubation in PBS; in these cases a 'preaggregation' period of about $7 \mathrm{~h}$ occurred before the beginning of aggregation, so that complete development required about $24 \mathrm{~h}$.

Development and labelling. Cells prepared as indicated above were washed twice in PBS, once in 'development buffer' (DB; per litre: $1.5 \mathrm{~g} \mathrm{Na}_{2} \mathrm{HPO}_{4}, 4.0 \mathrm{~g} \mathrm{KH}_{2} \mathrm{PO}_{4}, 1.5 \mathrm{~g} \mathrm{KCl}, 0.5 \mathrm{~g} \mathrm{MgCl}_{2} .6 \mathrm{H}_{2} \mathrm{O}, 0.5 \mathrm{~g}$ streptomycin sulphate, pH 6.5) and suspended at $\mathrm{I} \times 10^{8} \mathrm{ml}^{-1}$ in DB. Samples $(0.5 \mathrm{ml})$ were evenly spread on each of several Millipore filters $(47 \mathrm{~mm}, 0.8 \mu \mathrm{m}$ pores, black, grids, on pads pre-wet with $1.2 \mathrm{ml} \mathrm{DB}$ ). These were contained in small plastic Petri dishes; other pads saturated with $1 \mathrm{~m}$-phosphate buffer, $\mathrm{pH} 6 \cdot 5$, were stuck to the insides of the lids to improve synchrony of development. These dishes were incubated at $23^{\circ} \mathrm{C}$ at high humidity in closed plastic boxes in the dark. For most pulse-labelling experiments, the filter with developing cells was removed from the support pad at the desired time, blotted briefly on the bottom on a tissue to remove excess buffer, placed on $0.1 \mathrm{ml}$ DB containing the desired labelled precursor, and incubated in the humidified box for $1.5 \mathrm{~h}$ at $23^{\circ} \mathrm{C}$. In some cases, label in 0.5 to $1.0 \mathrm{ml} \mathrm{DB}$ was applied to the top of the developing cells on the filter. Although the absolute level of labelling depended somewhat on the method of label application, the specific activity, and the label concentration, the relative patterns of labelling of the different types of DNA did not depend on these variables in the range used here. No unlabelled precursor was added in addition to that already in the commercial radioactive sample. For quantitative comparisons of label uptake at various stages of development, results are presented relative to uptake under identical conditions for a $1.5 \mathrm{~h}$ pulse starting at $10 \mathrm{~h}$ of development. Labelled precursors were: [methyl${ }^{3} \mathrm{H}$ thymidine [ 18 to $50 \mathrm{Ci} \mathrm{mmol}^{-1}\left(1 \mathrm{Ci}=1 \times 10^{10}\right.$ becquerels), Amersham or New England Nuclear]; deoxy[G${ }^{3} \mathrm{H}$ ]adenosine (15 to $25 \mathrm{Ci} \mathrm{mmol}^{-1}$, Amersham or New England Nuclear); [2- $\left.{ }^{-} \mathrm{H}\right]$ adenine (20 to $35 \mathrm{Ci} \mathrm{mmol}^{-1}$, New England Nuclear); [methyl- ${ }^{3} \mathrm{H}$ ]thymine $\left(20 \mathrm{Ci} \mathrm{mmol}^{-1}\right.$, New England Nuclear). Further details of labelling are given in the figure legends.

Cell lysis and CsCl gradients. After pulse-labelling the cells were washed from the filters and disaggregated either mechanically by rapid pipetting or chemically with $1 \mathrm{mg}$ pronase $\mathrm{ml}^{-1}$ and $10 \mathrm{mM}$-2,3-dimercaptopropanol in 50 mM-Tris, pH 7 (Takeuchi \& Yabuno, 1970; Ford \& Deering, 1979). The method of disaggregation did not affect the labelling patterns. These cells were washed once in $0.1 \mathrm{M}$-EDTA, $\mathrm{pH} 8$, resuspended in $1.54 \mathrm{ml}$ of the same, lysed with $0.46 \mathrm{ml}$ of $20 \%(\mathrm{w} / \mathrm{w})$ sodium lauryl sarcosine, immediately added to $0.54 \mathrm{~g} \mathrm{CsCl}$, and heated to 60 to $70^{\circ} \mathrm{C}$ for $10 \mathrm{~min}$ (Kielman \& Deering, 1980). These lysates were stored at $-70^{\circ} \mathrm{C}$ for analysis later.

For $\mathrm{CsCl}$ gradients, 0.4 to $0.7 \mathrm{ml}$ of lysate was mixed with enough netropsin stock solution $\left(100 \mu \mathrm{g} \mathrm{ml}^{-1}\right.$ in $0.01 \mathrm{M}$-Tris, $0.001 \mathrm{M}$-EDTA, $\mathrm{pH} \mathrm{7.4)}$ to yield $50 \mu \mathrm{g}$ netropsin per $\mathrm{ml}$ lysate. This mixture was held at room temperature for 20 to 30 min prior to the addition of enough $\mathrm{CsCl}$ and $\mathrm{H}_{2} \mathrm{O}$ to yield a final volume of $6.2 \mathrm{ml}$ at a density of $1.62 \mathrm{~g} \mathrm{ml}^{-1}$. The netropsin was kindly supplied by Dr E. L. Patterson of Lederle Laboratories. In some initial experiments, the netropsin concentration was varied in the lysates in order to determine the optimum necessary for maximum enhancement of resolution of the DNAs (see Results). Centrifugation was in a $50 \mathrm{Ti}$ rotor at 30000 r.p.m. $(70000 \mathrm{~g})$ for $65 \mathrm{~h}$ at $20^{\circ} \mathrm{C}$. Thirty fractions $(0.2 \mathrm{ml} \mathrm{each})$ were collected from each gradient, $0.2 \mathrm{ml}$ of $2 \mathrm{M}-\mathrm{KOH}$ containing $20 \mu \mathrm{g}$ of calf thymus carrier DNA (Worthington) was added to each, these were incubated at $37^{\circ} \mathrm{C}$ for 2 to $3 \mathrm{~h}$ to hydrolyse the RNA, the DNA was precipitated with $4 \mathrm{ml}$ of ice-cold $5 \%$ TCA for $1 \mathrm{~h}$, and the TCA-insoluble precipitate collected on filters $(25 \mathrm{~mm}, 0.45 \mu \mathrm{m}$ pore $)$ in a multiple-filter manifold. Each was 
washed with more ice-cold 5\% TCA, then cold water, and dried and counted (Kielman \& Deering, 1980). ${ }^{14} \mathrm{C}$ labelled $\mathrm{m}$ - and $\mathrm{n}$-DNA from vegetative cells were included in each gradient as density markers (Kielman \& Deering, 1980); only the peak positions of these markers are indicated in the figures.

Gamma irradiation from $a^{60} \mathrm{Co}$ source. Developing cells were irradiated at about $10^{\circ} \mathrm{C}$ on the filters and pads immediately or at a measured time before the pulse-labelling period started. The source was a Gammacell 200 (Atomic Energy of Canada) and the dose rate was $21 \mathrm{krad} \mathrm{min}^{-1}$.

\section{RESULTS}

\section{Constitutive uptake of DNA precursors during development}

Netropsin preferentially attaches to the AT base-pairs of DNA, thereby reducing the density of the DNA and enhancing the resolution of different density species on $\mathrm{CsCl}$ gradients (Zimmer, 1975). This phenomenon has been utilized here and in other studies on $D$. discoideum (Firtel et al., 1976; Kielman \& Deering, 1980) to enhance the resolution of the mitochondrial, satellite, and main-band n-DNA. For $50 \mu \mathrm{g}$ netropsin or greater per ml cell lysate, the DNA was reduced in density by about $0.06 \mathrm{~g} \mathrm{ml}^{-1}$ and the separation of $\mathrm{m}-$ and $\mathrm{n}$-DNAs was increased from about $0.6 \mathrm{ml}$ (three fractions) with no netropsin to about $1.0 \mathrm{ml}$ (five fractions) with netropsin. Netropsin was used in all gradients.

The patterns of uptake for thymidine (dT), deoxyadenosine (dA) and adenine (A) into $D$. discoideum DNA for a $1.5 \mathrm{~h}$ pulse-labelling period from 5 to $6.5 \mathrm{~h}$ (late aggregation) or 10 to 11.5 $\mathrm{h}$ (early culmination) of development are shown in Fig. 1. Any labelled RNA banding at the bottom of these gradients was hydrolysed by the alkaline treatment of the fractions and is not seen. Some labelled material of unidentified origin is often seen at the top of the gradients, but this will not be considered further here.

Thymidine and deoxyadenosine gave similar labelling patterns throughout development. In early development, typified by the late aggregation period ( 5 to $6.5 \mathrm{~h}$ pulse) label was incorporated only into DNA of mitochondrial (or satellite I) density. No detectable incorporation into main-band n-DNA was observed. Although the possibility cannot yet be completely excluded that the observed incorporation at 5 to $6.5 \mathrm{~h}$ is in part into nuclear satellite I DNA, which bands at almost the same density as m-DNA, the majority of the incorporation at that time is probably into m-DNA. This conclusion is favoured by nuclear isolation experiments and by the observation that little satellite at higher density (II) is labelled. Hence, label was not incorporated generally into the satellites at this time. However, to include the possibility that some labelled satellite I DNA might be included under the peak, this peak will be designated 'm,s-DNA' throughout this report, even though most is probably m-DNA, at least early in development. No adenine was incorporated into the $\mathrm{m}, \mathrm{s}$ peak at late aggregation.

Later in development, starting at about $7 \mathrm{~h}$ for aggregation-competent cells $(14 \mathrm{~h}$ for noncompetent), incorporation of $\mathrm{dT}, \mathrm{dA}$ and $\mathrm{A}$ occurred to an increasing degree in the main-band $\mathrm{n}$ DNA, as typified by the gradients for early culmination (10 to $11.5 \mathrm{~h}$; right panel of Fig. 1). In the period 9 to $13 \mathrm{~h}$ of development, incorporation into the n-DNA greatly exceeded that into m,s-DNA. In addition to some incorporation at the position of m,s-DNA, it is of note that DNA at the density of satellite II (to the dense, i.e. left side of the $\mathrm{m}, \mathrm{s}$ position) was also labelled reproducibly at these later times, in a proportion to be expected for this DNA relative to the main-band n-DNA. With dT and dA, satellite I DNA is probably also labelled to about the same extent as satellite II, but this label is at the same position as the m-DNA (combined incorporation labelled ' $\mathrm{m}, \mathrm{s}$ ') and therefore cannot be easily quantitated. However, for adenine, the uptake is apparently totally into n-DNA and satellites I and II since the proportions of label in these three peaks is correct for that situation (lower right panel, Fig. 1). In all gradients with labelled adenine, the label incorporated at the densities of satellites I and II kept a constant proportion (about $5 \%$ each) relative to the main-band n-DNA, as did the satellite II peak for dT and $\mathrm{dA}$ (I being under $\mathrm{m}-\mathrm{DNA}$ and hence not separable). These results suggest that incorporation into these nuclear satellite DNAs yields the same specific activity DNA as the main-band nuclear component, and that differential incorporation into satellite I, II, and nDNA has not occurred. It is concluded that no incorporation of labelled adenine into m-DNA 


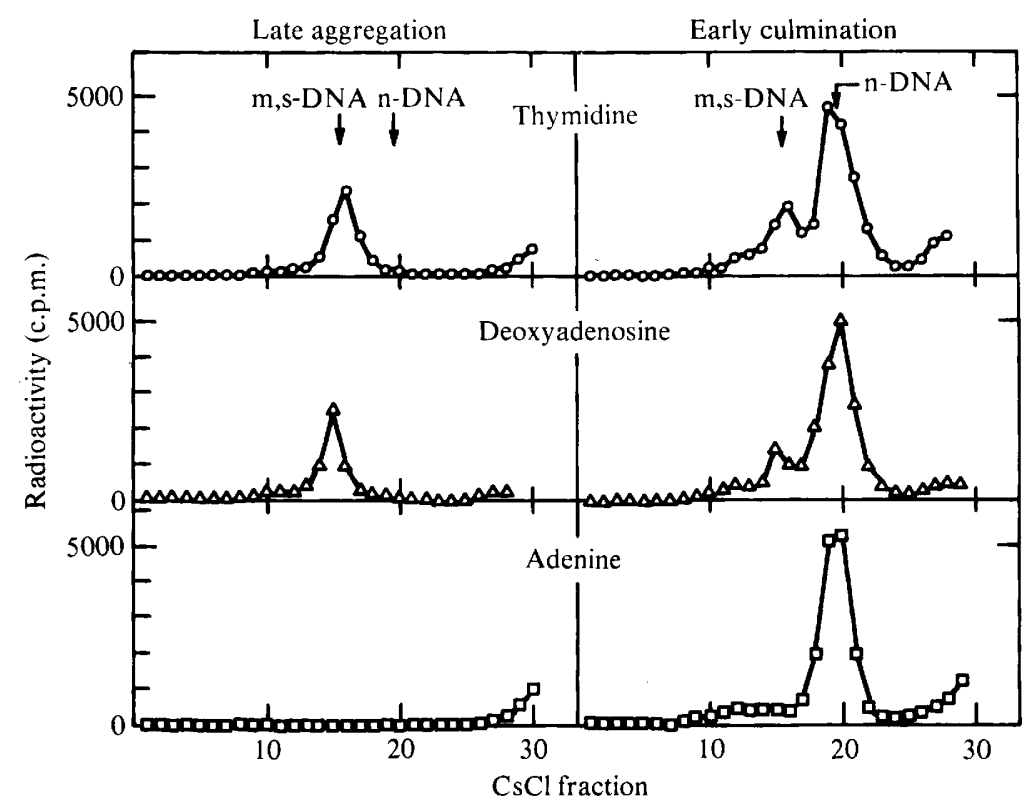

Fig. 1. $\mathrm{CsCl}$ gradient profiles for label uptake into DNA of $D$. discoideum during development. Left panels: late aggregation, pulse label from 5 to $6.5 \mathrm{~h}$ of development. Right panels: early culmination, pulse label from 10 to $11.5 \mathrm{~h}$ of development. Resolution enhanced by netropsin in all cases. Density increases to the left. Positions of ${ }^{14} \mathrm{C}$-marker DNA from vegetative cells are indicated by arrows: $\mathrm{m}, \mathrm{s}-$ DNA, mitochondrial-satellite I position; n-DNA, nuclear main-band position. Thymidine: [methyl$\left.{ }^{3} \mathrm{H}\right]$ thymidine, $50 \mathrm{Ci} \mathrm{mmol}^{-1}, 200 \mu \mathrm{Ci}$ in $1 \mathrm{ml} \mathrm{DB}$ spread on surface of developing aggregates on the filter. Deoxyadenosine: deoxy[G- $\left.{ }^{3} \mathrm{H}\right]$ adenosine, $25 \mathrm{Ci} \mathrm{mmol}^{-1}, 50 \mu \mathrm{Ci}$ in $0 \cdot 1 \mathrm{ml} \mathrm{DB}$ below the filter. Adenine: $\left[2{ }^{-3} \mathrm{H}\right]$ adenine, $32 \mathrm{Ci} \mathrm{mmol}{ }^{-1}, 200 \mu \mathrm{Ci}$ in $1.0 \mathrm{ml} \mathrm{DB}$ above aggregates on the filter.

occurred at any stage of development under the conditions used here. However, it is to be noted that incorporation of labelled adenine into m-DNA does occur for cells labelled in vegetative growth (Kielman \& Deering, 1980).

No incorporation of thymine into any DNA at any stage of development has been observed, constitutively or radiation-induced (data not shown), nor is any labelled thymine taken up into the DNA of vegetative cells (C. A. Michrina and J. K. Kielman, personal communications).

The results of numerous gradients such as those of Fig. 1 for many times throughout development are summarized in Fig. 2. The integrated counts under the $m, s-$ and n-DNA peaks relative to the n-DNA at the 10 to $11.5 \mathrm{~h}$ point are plotted as a function of the time at the midpoint of the $1.5 \mathrm{~h}$ pulse-labelling period for $\mathrm{dT}, \mathrm{dA}$ and $\mathrm{A}$. The X-points are for uptake of $\mathrm{dT}$ during development of cells not having undergone an 8 to $10 \mathrm{~h}$ preincubation in buffer before the start of development, with $7 \mathrm{~h}$ of preaggregation time subtracted to normalize the developmental stage. When normalized in this way, the stage specificity of the uptake of the dT is the same for these two protocols. Although as detailed earlier, it is believed that the uptake observed at the m,s-DNA density for adenine is all due to satellite I, the vertical bars plotted for A at the later times are a reminder of some uncertainty as to the true nature of this DNA. All data are normalized to lysates of equal numbers of cells.

Uptake of dT and dA into the m,s-DNA occurred throughout development, with a broad peak at 4 to $8 \mathrm{~h}$, during the late aggregation period. As discussed earlier, there was no good evidence for uptake of adenine into m-DNA at any stage. However, uptake into main-band nDNA and nuclear satellites I and II did occur during the later stages of development. Prior to about $7 \mathrm{~h}$ of development, no uptake of dT, dA or A occurred in n-DNA. Uptake of all three precursors into n-DNA then rapidly increased, reaching a peak between 9 and $13 \mathrm{~h}$ of development, in the early to mid-culmination stages. 


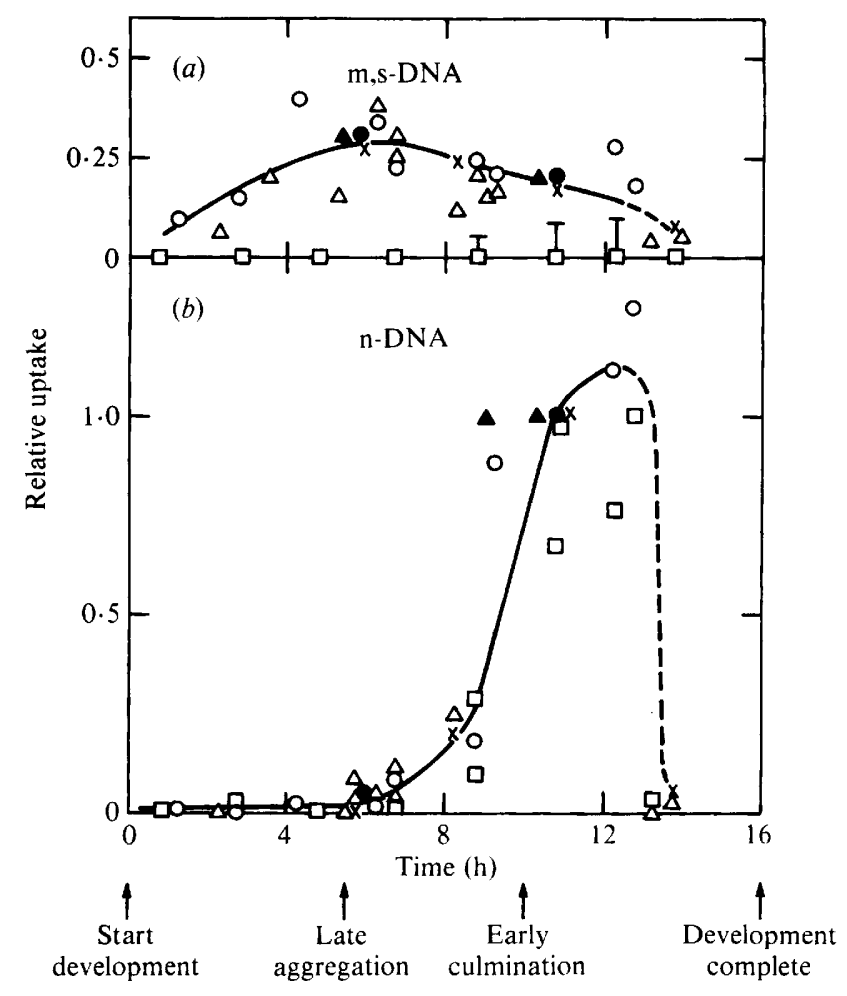

Fig. 2. Relative uptake of labelled precursors into m,s-DNA $(a)$ or n-DNA $(b)$ as a function of the midpoint of the $1.5 \mathrm{~h}$ pulse label during development. Each uptake value was determined by integration of counts under the appropriate peak on $\mathrm{CsCl}$ gradients such as those of Fig. 1. Uptake was normalized to 1.0 for $n$-DNA with the $1.5 \mathrm{~h}$ pulse starting at $10 \mathrm{~h}$. Developmental stages are indicated at the bottom of the figure. Open symbols: single experiments; closed symbols: average of several experiments for identical times and conditions. $O$, Thymidine; $\triangle, \Delta$, deoxyadenosine; $\square$, $\square$, adenine; $X$, thymidine, for development with no preincubation in buffer; times were normalized to same stage of development by subtracting $7 \mathrm{~h}$ preaggregation period at start of development.

For times later than $13 \mathrm{~h}$, little if any incorporation could be detected for any of the precursors. At this stage, spore and stalk-cell differentiation were well advanced and cell lysis was less than complete. Although the results at these later times suggest little actual uptake of label, poor lysis may have been a contributing factor; this region of uncertainty is indicated by the dashed lines in Fig. 2.

\section{Gamma ray modification of uptake patterns}

Various physical and chemical agents which damage DNA, such as UV light, ionizing radiation and mutagenic chemicals, are expected to stimulate repair replication of DNA (see Hanawalt et al., 1978). This is sometimes manifested as 'unscheduled' DNA synthesis under conditions when normal semiconservative replication is absent or suppressed. In addition, these agents usually depress constitutive semiconservative replication, at least temporarily (Deering \& Jensen, 1973; Kielman \& Deering, 1980). Changes of these types as manifested by changes in precursor uptake were sought in the present series of experiments. Gamma rays from a ${ }^{60} \mathrm{Co}$ source were used as the damaging agent because no changes in penetration and degree of damage would occur during aggregation and development of multicellular clumps; pronounced changes in effective damage within such clumps would be expected for UV light and possibly chemicals, hence complicating the use of these agents.

Typical results for the gradient profiles of $\left[{ }^{3} \mathrm{H}\right]$ thymidine uptake following gamma irradiation 


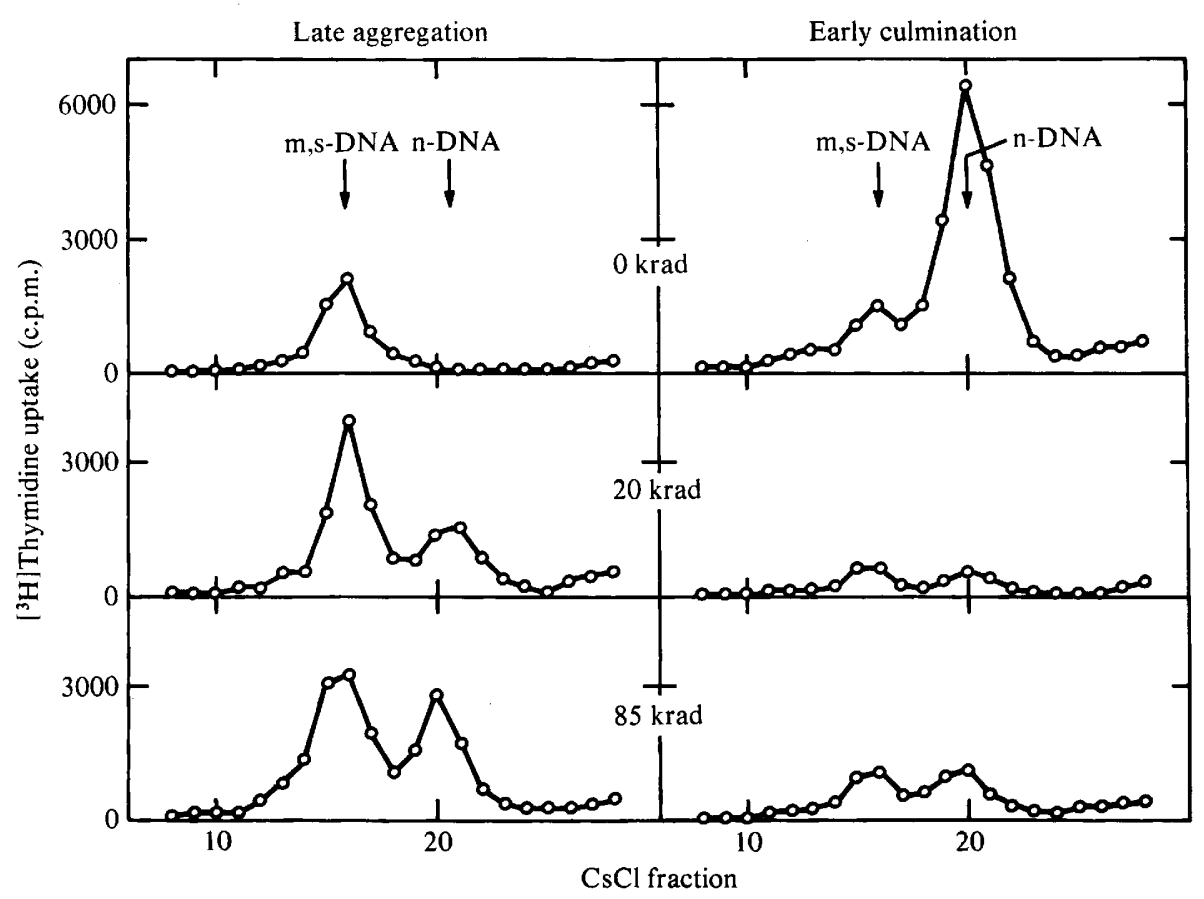

Fig. 3. Gamma ray (from a ${ }^{60} \mathrm{Co}$ source) induced changes in patterns of uptake for $\left[{ }^{3} \mathrm{H}\right]$ thymidine at late aggregation (left) or early culmination (right). The $1.5 \mathrm{~h}$ pulse label started immediately after the indicated radiation dose. The labelled precursor used was [methyl- ${ }^{3} \mathrm{H}$ ] thymidine, $50 \mu \mathrm{Ci}$ in $0 \cdot 1 \mathrm{ml} \mathrm{DB}$ beneath the filter (sp. act. $19 \mathrm{Ci} \mathrm{mmol}^{-1}$ ).

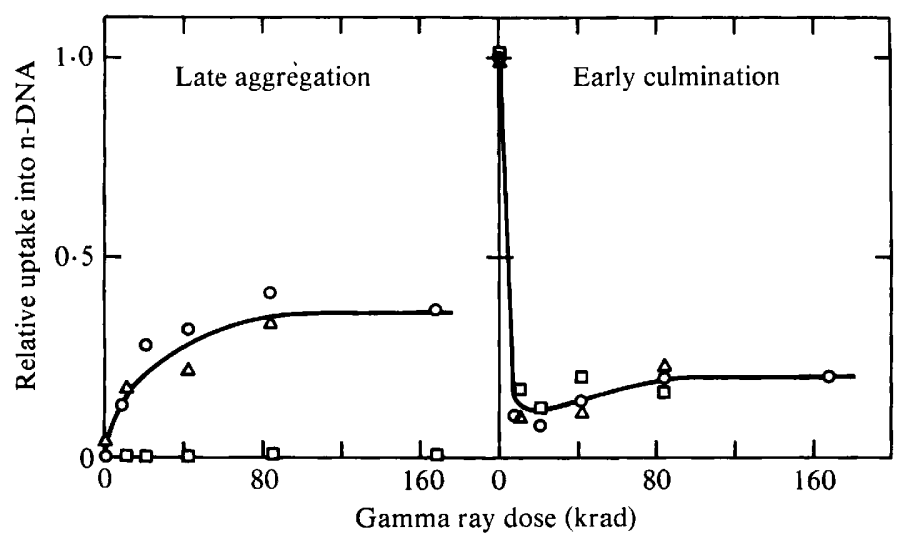

Fig. 4. Relative uptake into n-DNA at late aggregation or early culmination as a function of gamma ray dose. Normalized to 1.0 for control n-DNA at early culmination. Each point is the integral under the nDNA peak from a gradient of the type shown in Fig. 3. $O$, Thymidine; $\triangle$, deoxyadenosine; $\square$, adenine. All labelling was for $1.5 \mathrm{~h}$ with $50 \mu \mathrm{Ci}$ in $0.1 \mathrm{ml} \mathrm{DB}$ below the filter.

during development are shown in Fig. 3. For these cases, the pulse of labelling was started just after the irradiation. Several effects are immediately apparent. (1) At late aggregation (5 to $6.5 \mathrm{~h})$ reproducible and easily quantitated uptake into n-DNA was induced by the gamma irradiation. (2) In general, little reproducible change in uptake into m,s-DNA occurred for the dose range used here ( 0 to $165 \mathrm{krad})$ either at the early or late stages of development. (3) Later in 
development, when constitutive uptake into n-DNA was high, the gamma irradiation severely depressed the uptake into this DNA at doses as low as $10 \mathrm{krad}$ (early culmination, Fig. 3).

The results for gamma ray induced changes in the uptake of $\mathrm{dT}, \mathrm{dA}$ and $\mathrm{A}$ into the n-DNA are summarized in Fig. 4. At late aggregation, uptake of dT and dA into n-DNA were stimulated to the same degree. Uptake of adenine was not induced. At early culmination, constitutive uptake of $\mathrm{dT}, \mathrm{dA}$ and $\mathrm{A}$ into n-DNA were all depressed, initially to a level of about $10 \%$ at 10 to $20 \mathrm{krad}$. A subsequent small increase in uptake then occurred in the dose range 20 to $80 \mathrm{krad}$. It is of note that $100 \mathrm{krad}$ of gamma rays has little effect on the ultimate survival of these cells; the $50 \%$ survival dose is $200 \mathrm{krad}$ (Deering et al., 1970; Welker \& Deering, 1978). There is also little effect of $100 \mathrm{krad}$ on development (Deering et al., 1972).

When the start of the labelling pulse was delayed for $3 \mathrm{~h}$ after a dose of $21 \mathrm{krad}$, no induced uptake was observed into the n-DNA for irradiation at late aggregation $(5 \mathrm{~h})$, nor was any depression observed for uptake of dT into n-DNA for irradiation at early culmination $(10 \mathrm{~h})$. Hence the changes depicted in Fig. 4 are transitory and the normal pattern of precursor uptake returned within a $3 \mathrm{~h}$ post-irradiation period for this dose.

\section{DISCUSSION}

Important questions are posed by these results. (1) What is the basis of the stage-dependent constitutive uptake of the precursors into the $\mathrm{m}(\mathrm{s}$ ?)- and main-band n-DNA? More specifically: (a) what underlies the uptake of dT and dA only into the m,s-DNA early in development, with no accompanying uptake into main-band n-DNA prior to $7 \mathrm{~h}$ ? (b) why is there no uptake of adenine into the m,s-DNA at any stage of development, whereas uptake into n-DNA does occur? (c) what is the basis for the strong preferential uptake of all three precursors (dT, dA, A) into the main-band n-DNA starting at about $7 \mathrm{~h}$ of development and continuing throughout early and mid-culmination? (2) (a) What is the nature of the gamma ray induced uptake of dT and dA into n-DNA early in development? (b) Why is there no induced uptake of A into n-DNA at this time? (c) What underlies the pronounced gamma-induced depression of constitutive label incorporation of all three precursors into n-DNA later in development? (d) Lastly, why are the gamma rays exerting little effect on the precursor uptake into m,s-DNA, either early or later in development? Although definitive answers to many of these questions are not available at present, some possibilities seem worthy of discussion.

\section{Constitutive uptake of precursors}

As outlined earlier, it is likely that the DNA labelled early in development (termed m,s-DNA) is mostly m-DNA, although the existence of some satellite DNA labelling cannot be completely excluded. The DNA labelled later in development is mainly nuclear main-band DNA. Since the cells used at the start of development were usually preincubated in buffer with no nutrient for about $9 \mathrm{~h}$, and since no uptake into n-DNA was observed for the first $6 \mathrm{~h}$, it is improbable that the observed uptake patterns arise from residual vegetative growth of the cells. Something more specific appears to be involved, due to the synchronous development of the cells, such as the cellcycle changes $\left(G_{1}, S, G_{2}, M\right)$ considered by Katz \& Bourguignon (1974) and the division and nDNA labelling kinetics observed by Zada-Hames \& Ashworth (1978). The latter work appears most related to our results. These investigators observed a stage-dependent period of cell division and nuclear labelling (autoradiographic studies) mainly at the 'grex' stage in the development of stationary phase cells, and an additional earlier such event during the 'preaggregation' stage of development as started from vegetative cells.

The period of n-DNA labelling observed here corresponds closely to the 'grex'-specific division and nuclear labelling observed by Zada-Hames \& Ashworth for development of stationary phase cells which show only a very brief preaggregation period, as do the preincubated cells used here. The significance of this developmentally correlated period of division of some of the cells and associated synthesis of n-DNA is obscure but may be of considerable importance (see below). The uptake of dT and dA into m,s-DNA throughout 
development suggests an extended period of synthesis of m-DNA, with a broad maximum at late aggregation. However, no uptake of A into m,s-DNA was observed at any stage.

These results indicate that there are significant changes throughout development in some or all of the following intermediate events in the incorporation of these precursors into DNA, and that at least some of the changes are different for m- and n-DNA synthesis: (1) transport of precursors into the intracellular pools and/or transport of intermediates between metabolic pools within the cells; (2) pool sizes of precursor intermediates and/or deoxynucleoside triphosphates; (3) developmental regulation of the availability of the enzymes involved in the metabolic processing of the precursors and/or enzymes directly involved in DNA replication, such as binding proteins, topoisomerases, nucleases, polymerases, ligases, or others and (4) more direct regulation of the replication of specific, random, or general portions of the DNA via structural changes or rearrangements such as recombination, other forms of genetic modification, transcription, or derepression by certain regulatory processes associated with development.

Even though the present results do not allow one to distinguish between these possibilities, it is clear that significant developmentally associated changes are occurring in at least some of these processes. Since these may reflect important aspects of developmental regulation in this organism, it would be of considerable interest to investigate these phenomena further. The possibility that the observed precursor uptake is not uniform throughout the DNA, but that it may represent synthesis or amplification of only specific portions of regulatory or informational DNA should also be considered.

\section{Gamma ray induced changes in precursor uptake}

Little consistent gamma ray induced change in uptake of any of the precursors into m,s-DNA was observed in the dose range used here ( 0 to $165 \mathrm{krad})$. This relative resistance is qualitatively consistent with the previously observed resistance to gamma rays (Deering \& Jensen, 1973) or UV light (Kielman \& Deering, 1978) of changes in precursor uptake into m-DNA in vegetative cells. However, a meaningful quantitative comparison for the gamma ray results is difficult since the previous work related to internal uptake of precursor from labelled bacterial DNA during vegetative growth, whereas the current results pertain to exogenous precursor uptake during development. The involvement of precursor transport and pool sizes may be very different in these cases. The molecular basis for the refractiveness of precursor uptake into mDNA to change by gamma rays is not known, although differences in mode of DNA replication, relatively small target size, and/or pool size are probably involved (Deering \& Jensen, 1973). Two important consequences of gamma irradiation were observed for the n-DNA: (1) at late aggregation, when little if any constitutive uptake was observed into this DNA, uptake of dT and $\mathrm{dA}$ was induced by the gamma rays to a level of about $35 \%$ of the constitutive uptake observed at later stages (left panel, Fig. 4); (2) later in development, at the early culmination stage, the already pronounced constitutive uptake of $\mathrm{dT}, \mathrm{dA}$ and $\mathrm{A}$ into main-band n-DNA was severely depressed by gamma rays, to a level of about $10 \%$ at $20 \mathrm{krad}$; a subsequent slight increase back to a level of about $20 \%$ of the control occurred in the dose range 20 to $80 \mathrm{krad}$. Although no direct molecular evidence is currently available, it is tempting to postulate that: (a) the induced uptake at late aggregation is attributable to an 'unscheduled' synthesis of n-DNA, possibly due to repair replication of gamma-damaged DNA (see Hanawalt et al., 1978, for reviews of repair replication in several systems); (b) the gamma ray induced decrease in uptake at low doses ( 0 to $20 \mathrm{krad})$ at early culmination is due to a depression of constitutive semiconservative DNA replication and (c) the subsequent slight rise in uptake at higher doses at early culmination represents superimposed induced repair synthesis, as observed at the earlier times. However, the potential dependence of the uptake on other factors such as transport and precursor pool size makes these conclusions tentative until further studies of these factors are available.

The changes observed here may be of considerable importance in our understanding of $D$. discoideum development and DNA repair. However, the complexity of the processes involved in precursor uptake into the various types of DNA of this organism precludes a definite 
interpretation at present. Further knowledge of transport phenomena, DNA precursor pool sizes, and DNA replication and repair in this organism will be required.

This investigation was supported by grants from the National Institutes of Health, General Medical Sciences GM16620 and Cancer CA01014. The technical assistance of Mary Sheely with some of the experiments is gratefully acknowledged. Part of this research was done while the author was on leave at the laboratory of Dr Philip Hanawalt, Department of Biological Sciences, Stanford University, Stanford, California. I thank him and his associates for the use of their facilities and for their advice and kind support.

\section{REFERENCES}

BoNNER, J. T. (1967). The Cellular Slime Molds. Princeton: Princeton University Press.

Bonner, J. T. \& Frascella, E. B. (1952). Mitotic activity in relation to differentiation in the slime mold Dictyostelium discoideum. Journal of Experimental Zoology 121, 561-571.

Clark, J. M. \& Deering, R. A. (1981). Excision of pyrimidine dimers from nuclear deoxyribonucleic acid in ultraviolet-irradiated Dictyostelium discoideum. Molecular and Cellular Biology 1, 121-127.

DEERING, R. A. \& JENSEN, D. S. (1973). Nuclear and mitochondrial DNA synthesis in gamma ray-resistant and -sensitive slime mold amoebas. Biophysical Journal 13, 780-794.

Deering, R. A., Smith, M. S., Thompson, B. K. \& ADOLF, A. C. (1970). Gamma-ray-resistant and -sensitive strains of slime mold (Dictyostelium discoideum). Radiation Research 43, 711-728.

Deering, R. A., Adolf, A. C. \& Silver, S. M. (1972). Independence of propagation ability and developmental processes in irradiated cellular slime molds. International Journal of Radiation Biology 21, 235245.

FiRTEL, R. A. \& BonNER, J. (1972). Characterization of the genome of the cellular slime mold Dictyostelium discoideum. Journal of Molecular Biology 66, 339-361.

Firtel, R. A., Cockburn, A., Frankel, G. \& HERSHFIELD, V. (1976). Structural organization of the genome of Dictyostelium discoideum : analysis by EcoRI restriction endonuclease. Journal of Molecular Biology 102, 831-852.

Ford, W. T., JR \& DEering, R. A. (1979). Survival, spore formation and excision repair of UVirradiated developing cells of $D$. discoideum. Photochemistry and Photobiology 30, 653-659.

Guialis, A. \& DEERING, R. A. (1976). Repair of deoxyribonucleic acid in ultraviolet light-sensitive and -resistant Dictyostelium discoideum strains. Journal of Bacteriology 127, 59-66.
Hanawalt, P. C., Friedberg, E. C. \& Fox, C. F. (editors) (1978). DNA Repair Mechanisms. New York: Plenum Publishing Company.

Katz, E. R. \& Bourguignon, L. Y. W. (1974). The cell cycle and its relationship to aggregation in the cellular slime mold, Dictyostelium discoideum. Developmental Biology 36, 82-87.

KielmaN, J. K. \& DeERING, R. A. (1980). Ultraviolet light-induced inhibition of cell division and DNA synthesis in axenically grown repair mutants of Dictyostelium discoideum. Photochemistry and Photobiology 32, 149-156.

LoOMIS, W. F., JR (1975). Dictyostelium discoideum: A Developmental System. New York: Academic Press.

Ohnishi, T., OKaichi, K., OHashi, Y. \& NozU, K. (1981). Effect of caffeine on DNA repair of UVirradiated Dictyostelium discoideum. Photochemistry and Photobiology 33, 79-83.

Sussman, R. \& Rayner, E. P. (1971). Physical characterization of deoxyribonucleic acids in Dictyostelium discoideum. Archives of Biochemistry and Biophysics 144, 127-137.

TAKEUCHI, I. \& YaBUNO, K. (1970). Disaggregation of slime mold pseudoplasmodia using EDTA and various proteolytic enzymes. Experimental Cell Research 61, 183-190.

WeLKER, D. L. \& DeERING, R. A. (1978). Genetics of radiation sensitivity in the slime mould Dictyostelium discoideum. Journal of General Microbiology 109, 1123.

ZaDa-Hames, I. M. \& Ashworth, J. M. (1978). The cell cycle and its relationship to development in Dictyostelium discoideum. Developmental Biology 63, 307-320.

ZIMMER, C. (1975). Effects of the antibiotics netropsin and distamycin $\mathrm{A}$ on the structure and function of nucleic acids. Progress in Nucleic Acid Research and Molecular Biology 15, 285-318. 